\title{
Increase Representation in Mathematics Classes: Effects of Computer Assisted Instruction Development with Hippo Animator
}

\author{
Uba Umbara ${ }^{12^{*}}$, Munir $^{3^{* \star}}$, R. Susilana ${ }^{4^{* \star *}}$, Evan Farhan Wahyu Puadi ${ }^{1 * \star * \star}$ \\ ${ }^{1}$ Department of Mathematics Education, STKIP Muhammadiyah Kuningan, Kuningan, Indonesia \\ ${ }^{2}$ School of Postgraduate Studies, Universitas Pendidikan Indonesia, Bandung, Indonesia \\ ${ }^{3}$ Department of Computer Science Education, Universitas Pendidikan Indonesia, Bandung, Indonesia \\ ${ }^{4}$ Department of Curriculum \& Educational Technology, Universitas Pendidikan Indonesia, Bandung, Indonesia

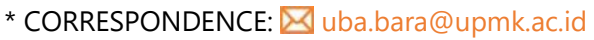 \\ ** CORRESPONDENCE: $\triangle$ munir@upi.edu \\ *** CORRESPONDENCE: $\square$ rudi_susilana@upi.edu \\ **** CORRESPONDENCE: $\$ evanfarhanwahyupuadi@upmk.ac.id
}

\begin{abstract}
This study is about developing and testing the effectiveness of Computer Assisted Instruction (CAI) through multimedia in mathematical representations. Features that are developed using the hippo animator provides learning instructions with the tutorial model. The principle of selfregulated learning and mastery learning are both the strategy in learning to ensure students to be able to learn to be self-sufficient and complete. The principles of reliability, usability, maintainability, compatibility, reliability, reliability, interactive and communicative are carried out to assess multimedia well designed in terms of interfaces to maximize mathematical representation. For these purposes, R \& D was selected in this study with structured and systematic stages through strict quality control. The results of the study show that multimedia developed is feasible to be produced and used in mathematics learning. Finally, the use of CAI through multimedia plays an important role in facilitating mathematical learning, especially in improving mathematical representation. However, the significance of differences in improving students' mathematical skill in representation ability is not found.
\end{abstract}

Keywords: mathematical representation, computer assisted instruction, multimedia, hippo animator

\section{INTRODUCTION}

The development of mathematical abilities has always been a strategic issue in mathematics learning. This is inseparable from the main purpose of implementing mathematics learning itself which focuses on the mathematical thinking process. The main standards of mathematical processes consist of representation, problem-solving, reasoning, and proofing, connection and communication (NCTM, 2000). The essence of learning mathematics is to determine exactly what structure is used both on actual and contextual from a mathematical concept. Transformations between structures studied in mathematics are known as representations. Regarding abstract mathematical properties, representation is needed especially when people need access to mathematical ideas that can only be done through the representation of ideas themselves

Article History: Received 22 August $2019 \bullet$ Revised 23 October $2019 \bullet$ Accepted 23 October 2019

(C) 2020 by the authors; licensee Modestum Ltd., UK. Open Access terms of the Creative Commons Attribution 4.0 International License (http://creativecommons.org/licenses/by/4.0/) apply. The license permits unrestricted use, distribution, and reproduction in any medium, on the condition that users give exact credit to the original author(s) and the source, provide a link to the Creative Commons license, and indicate if they made any changes. 
(Killpatrick, Swafford, \& Findell, 2001). The use of various forms of mathematical representation is important to be the focus of attention in mathematics learning which can be derived from aspects of the process and evaluation of mathematics learning (Afriyani, Sa'dijah, Subanji, \& Muksar, 2018).

Mathematical representation is a component of the process related to the cognitive development of students in learning. The process of actual mathematical representation from one structure to another is a work in mathematics to determine exactly what structure is used in that representation. The development of representation by someone is intended to interpret and remember experiences to understand the world (Salkind \& Hjalmarson, 2007). In other terms, representation is a configuration process of a situation that serves to provide interpretation in other situations (Goldin \& Kaput, 1996), which can be used by students to interpret problems encountered (Ainsworth, 2006) to develop and optimize students' thinking skills, which is a construction process and abstraction of mathematical knowledge (Rahmawati, Hidayanto, Anwar, \& others, 2017). So, theoretically, representation is a translation of the reality of practical and complex problems that are comprehensive, theoretical and systematic that can support problem-solving.

The complexity of mathematical representation is felt in the field of applied mathematics such as shipping technology (Noblesse, Delhommeau, Huang, \& Yang, 2011), mechanical engineering (Haidar, Obeed, \& Jawad, 2011), energy management strategy (Wieczorek \& Lewandowski, 2017), system reliability logic differential calculus in the field of information technology (Zaitseva \& Levashenko, 2013) and information technology applications in developing the World Wide Web algorithm (Nguyen, Hui, \& Chang, 2012). This is evidence, a person's ability to represent symbols and mathematical structures are needed in various fields of daily life. However, it must be understood that representation is independent in terms of use and utilization because the representation can transform various concepts and structures that are used primarily in the function of abstraction of certain patterns in mathematical procedures.

Specifically, the relationship between mathematical representation and mathematical learning is divided into cognitive and perceptual representations, explanatory representations, representations in mathematics, and external symbolic representations (Kaput, 1987). This external symbolic representation influences in reflecting the internal representation of students' mathematical knowledge (Janvier, 1987). The use of various representations has an important role in mathematics learning (Cai \& Lester Jr, 2005) especially in expressing mathematical ideas (Bal, 2015), regulating their thinking (Cathcart, Pothier, Vance, \& Bezuk, 2000), helping to understand and interpret mathematical concepts (Pape \& Tchoshanov, 2001), and complete the translation of tasks by articulating different representations (Gagatsis \& Elia, 2004).

Based on the complexity of the representation role, it is important to understand the classification of representations so they can determine the types and the transformations of representation as inseparable parts of the context. The classification of representations initially consists of: active, iconic, and symbolic (Bruner, 1966). Enactively is done through action, iconic is done through visual images, while symbolic is done through words and language. The three types of representation are becoming wider, such extensions are mentioned as real-life experiences, and manipulative models, pictures or diagrams, verbal words, written symbols (Lesh, Landau, \& Hamilton, 1983). Real-life experiences and manipulative models are classified into active representations, images and diagrams are iconic representations, while verbal words and written symbols are symbolic representations.

The classification of representation that expanded is an ideal transformation by not eliminating the meaning contained in it. The form of transformation of representation even occurs through the transformation of problem situations into oral language and written language consisting of symbols, scripts, creative models, and static images (Lesh, Post, \& Behr, 1987); external representation system and internal representation system (Goldin, 1998). External representations arise based on the understanding that human cognition changes when interacting with the environment (Goldin, 1998). External representation is closely related to social activities carried out by the students themselves. Meanwhile, internal representation consists of verbal, imagination, formal mathematical notation, planning ability, and executive monitoring and control, and effective representation that can be developed as one's competence in solving problems (Goldin, 1998). The internal representation is the main component that is capable of being a positive conductor for external representations that have a causality relationship.

Meanwhile, there was also a classification of representations by eroding the imaginative side but more applicable in the process of understanding mathematical concepts. The classification includes the form of student interpretation through words (verbal), writing, pictures, tables, concrete objects, mathematical symbols and others (NCTM, 2000). The use of appropriate and adequate representation can bridge the 
formation of understanding mathematical concepts, both in one type of representation and between different representations. Representation embodies the mental picture of a learning process that can be understood based on mental development in a person. Concept representation, symbolization, mathematical models, contexts, and ideas can be done by students through exploration efforts on the problems given in learning. Therefore, the process of forming mathematical concepts can be played through mathematical representation comprehensively to gain knowledge and understanding of mathematics (Chen, Lee, \& Hsu, 2015).

Ideas in mathematics generally will appear along with the process of representation of mathematical ideas through direct or indirect stimuli related to understanding relevant initial concepts. However, comprehending mathematical concepts comprehensively is often a separate difficulty for students. In this case, the role of representation is needed to transform different concepts and mathematical structures. Some of the previous findings show that students who have problems with image representation experience difficulties in construction, show processes, and the results of mathematical solutions (Surya, Sabandar, Kusumah, \& Darhim, 2013). Most students do not have comprehensive ability to solve problems, students have weaknesses in visual representation, students think it is not important to make graphics, they only think about how to use the formula to solve problems (Minarni, Napitupulu, \& Husein, 2016). Conversely, it was found that students' difficulties in determining the symbolic representation that corresponds to the relationship represented in the graph or table (McCoy, Baker, \& Little, 1996), verbal representation, and symbolic representation in mathematical relationships are still low (Gagatsis* \& Shiakalli, 2004).

Based on this fact, the development and use of representation deserve serious attention in learning. Several previous studies that focused on developing mathematical representations have been carried out, such as the use of digital tools (Carreira, 2015), problem based learning (Tandiling, 2015), developing instruction materials based on joyful problem based learning (Minarni \& Napitupulu, 2017), think- talk-write model (Supandi, Waluya, Rochmad, Suyitno, \& Dewi, 2018), eye tracking method (Andrà et al., 2009), thinking strategy approach (Abdullah, Zakaria, \& Halim, 2012), project-based learning (Widakdo, 2017), and RMEbased progressive mathematization (Warsito, Darhim, \& Herman, 2018). Based on previous research, it is known that the cause of the weakness of mathematical representation ability is because it is difficult to bridge representation and change from one representation to another (Yerushalmy, 1997), there are three types of errors that explain students' weaknesses during the translation process: misinterpretation, implementation, and preservation (Adu-Gyamfi, Stiff, \& Bossé, 2012).

Therefore, we believe that the use of various representations in learning needs to be done well especially visually, then followed by examining the process of translation or transformation between various forms of representation as suggested by previous researchers (Bal, 2015). One alternative that can be used in maximizing various forms of visual representation in learning is through the use of multimedia learning through the support of computer-assisted instruction (CAI) approach. CAI is an ICT-based learning model that emphasizes causal activities and communication between humans and computer devices. Alan B. Salisbury defines CAI as the interaction between humans and machines in performing teaching functions using computer systems without intervention by instructors (Zhang, Watson, \& Banfield, 2007).

The phenomenon that occurs in the world of education sometimes difficult to distinguish between ICTbased learning and CAI model learning. Here it should be emphasized that CAI is one part of ICT learning. CAI is ICT learning, but ICT does not always use the CAI model. In general, ICTs are often used in demonstrations of the latest programs to anticipate the saturation of teacher rhetoric (Cuban, 2009). The teaching function is carried out entirely through a system that has been previously designed by a previously developed model. Previous researchers suggested several principles and strategies on effective ICT teaching models that emphasize activity-based approaches (Thomas \& Knezek, 2002), which are tailored to interest in the need to integrate ICT in learning (Richards, 2005). So, it is important to emphasize the classification of CAI to avoid bias both in terms of the content and process carried out.

Bryan classifies CAI in three models or categories, namely: (1) ad-lib by giving full access to students but the input is not controlled by a computer, (2) games and simulations are limited by game rules or simulation logic even though students have several initiatives, and (3) drill-and-practice and tutorials which are controlled learning and imply anticipation and branching in detail with the development of anticipated question frameworks (Carbonell, 1970). Drill-and-practice and tutorials are models that can be used to measure the extent of student understanding of a material concept. CAI does not only refer to the use of computer technology in presenting material but can be used to examine the development of student knowledge (Anohina, 2005). Based on this need, CAI can be developed through multimedia learning. The main reason for 
development is based on the principle of being durable and easy to carry, although it can take a lot of time in the development process.

Previous research stated that the use of ICT in science learning can support abstract reasoning abilities (Chang, Chen, Lin, \& Sung, 2008), in mathematics learning, can increase learning participation and higher test results (De Witte, Haelermans, \& Rogge, 2015). Meanwhile, the CAI model used in learning can reduce anxiety in bibliography teaching (Van Scoyoc, 2003), providing significant benefits to literacy skills, especially in phonological awareness (Macaruso \& Walker, 2008), can develop early literacy skills (Macaruso \& Rodman, 2011), effective in learning autism students (Pennington, 2010), increasing critical-thinking skills especially in problem-solving skills, at least in students with better exposure to mathematics, science, and techniques beforehand (Renshaw, Taylor, \& Reynolds, 1998). Based on the advice of previous researchers, regarding the importance of modification in CAI learning to understand the reasons for CAI is not more effective for some students. Thus, this study tries to develop CAI using multimedia with a territorial model that refers to selfregulated learning and mastery learning on students' mathematical representation abilities.

\section{METHOD}

This study uses educational research \& development models (Gall, Gall, \& Borg, 2007) adapted from a systematic design of instruction design (Dick, Carey, \& Carey, 2015) which is then modified into five stages. These stages are illustrated in Figure 1.

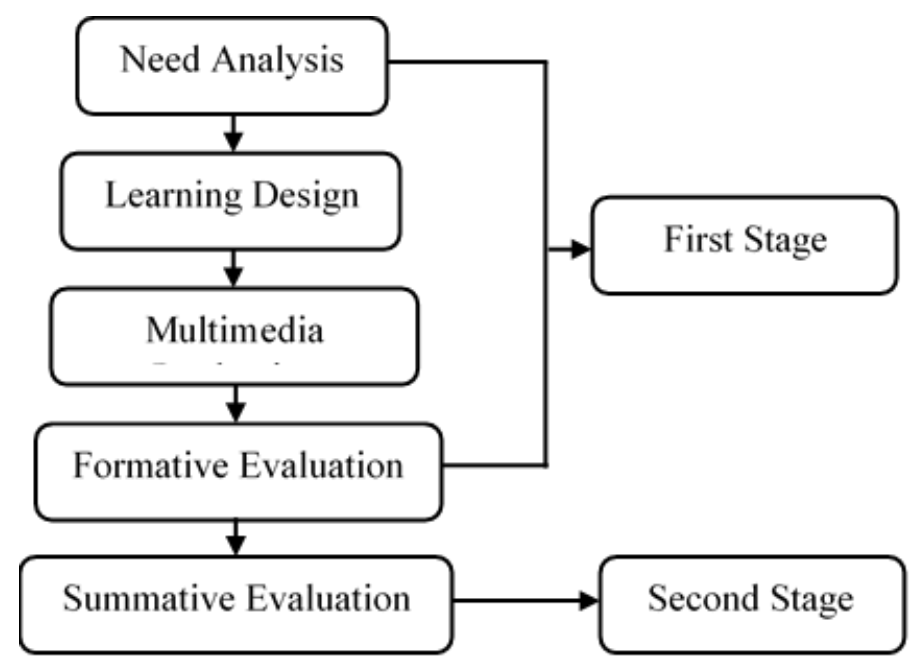

Figure 1. Procedure for R \& D in Multimedia Development

In the needs analysis phase, the researcher conducts literature studies and field studies, while at the learning design phase the researcher establishes competencies and indicators of learning, develops the material and points of the reference test and develops learning strategies. Media production is done through the stages of material collection, preparation of flowcharts and storyboards, ending with modular tests. Formative evaluation through the stages of validation of material experts and media experts, as well as media trials. Expert validation carried out using criteria, as shown in Table 1.

Table 1. The Criteria of Media Validation

\begin{tabular}{cc}
\hline Interval & Criteria \\
\hline $1.00 \leq \mathrm{x}<2.00$ & Not Valid \\
\hline $2.00 \leq \mathrm{x}<3.00$ & Less Valid \\
\hline $3.00 \leq \mathrm{x}<4.00$ & Valid \\
\hline $4.00 \leq \mathrm{x}<5.00$ & Very Valid
\end{tabular}

As depicted in Table 1, the standard used in this study is minimally valid, if the results of the validation show that the learning devices are not yet valid, then a revision of the learning device is being developed based on suggestions from reviewers. Meanwhile, in summative evaluation, the researcher used a quasiexperimental design which is a pretest-posttest control group design. The research instrument consisted of questionnaires, interview sheets, observation sheets, and mathematical representation ability test sheets. The 
question of the ability of mathematical representation is compiled based on the aspects and indicators of mathematical representation capabilities consisting of visual representations (diagrams, graphs, or tables), equations or mathematical expressions and written words or texts.

This development research uses two data analysis techniques, namely qualitative descriptive analysis techniques and quantitative analysis. This qualitative descriptive analysis technique is used to process the evaluation data by material experts, media experts and media trials conducted by students. This data analysis technique is done by grouping information from qualitative data in the form of inputs, responses, criticisms, and suggestions for improvements written on the questionnaire. The results of this analysis are then used to revise learning multimedia products. In this study, a minimum valid feasibility value was determined. If the results of the final assessment (overall) in each aspect of learning, aspects of content/material, appearance aspects and technical aspects with a minimum valid value, then the product of the development is considered appropriate to be used as a learning media. The analysis of the increase in mathematical representation ability was obtained from the results of pretest and posttest, which were processed using reference n-gain index data (Hake et al., 1999). Meanwhile, quantitative data analysis uses a two-way ANOVA test with a General Linear Model Univariate Analysis (GLM).

\section{RESULTS}

\section{Needs Analysis}

Needs analysis traced using questionnaire sheet instruments, in-depth interview and observation. Based on questionnaire analysis and in-depth interviews on the implementation of learning with respondents 20 students of class VII obtained results about the importance of the use of multimedia in learning. The basic reason is that most students feel difficulties in learning mathematical concepts and learning media used by teachers are still conventional. Observation results of the implementation of learning show that the use of media is still limited to the use of images/chat, handouts, job sheets, real objects, and simple power points. Besides that learning is often done in the classroom, although the laboratory facilities owned by the school are very adequate. So that mathematics learning so far has been less able to explore students' mathematical abilities with the discovery of various learning obstacles.

Based on a comprehensive literature review, researchers decided to develop interactive multimedia learning mathematics through the tutorial model. The researcher uses the hippo animator (hippani) as a development software. Hippani has several advantages, including a very lightweight application when compared to other software animators, so Hippani can be used on computers with medium specifications, equipped with tutorials so that it can be learned self-taught, and easy to operate without using a special player animator.

\section{Learning Design}

At the learning design stage the researcher sets competencies, indicators, and learning objectives, develops reference material and test items on statistical concepts (data presentation), identifies the initial character of students, develops test items, develops learning the material and develops learning strategies that will be used in the learning process. The CAI model was developed based on the principle of self-regulated learning and mastery learning with the tutorial model. Learning is done based on the stages of understanding concepts in a systematic and structured manner, students cannot continue learning if they have not completed learning based on specified criteria.

\section{Multimedia Production}

At this stage, the researcher carries out the media production process as an embodiment of ICT learning which is intended in this study. The stages of media production are carried out by steps: compiling an outline of media development, compiling flowcharts, storyboards, writing scripts, entering material into a computer, and modular tests. Modular tests are a way to functionally test media produced based on small parts that are interrelated. At this stage, we complete the media in the form of a prototype, considering that the media developed must pass the formative evaluation stage before the final product is produced.

\section{Formative Evaluation}

Formative evaluation through the stages of material expert validation and media experts, individual trials, small group trials, field trials until the final product was obtained. This stage was carried out as an effort to 
ensure that the media was developed through the quality control stage. Media experts are tasked with evaluating the media developed by conducting validations based on the suitability of storyboards and engineering aspects of soft anchors, aspects of audio-visual communication, aspects of presentation and aspects of appearance. The suitability of the media produced with flowcharts and storyboards must also be the main assessment of media experts. Meanwhile, the content expert conducts validation based on competence and learning objectives, conformity with material indicators, quality of material content and the content of the material presented. The results of the validation of two material experts and two media experts are shown in Table 2.

Table 2. The Results of Multimedia Development Validation

\begin{tabular}{ccc}
\hline Validator & Average Value & Category \\
\hline Content Expert I & 4.79 & Very Valid \\
\hline Content Expert II & 4.81 & Very Valid \\
\hline Media Expert I & 4.70 & Very Valid \\
\hline Media Expert II & 4.66 & Very Valid
\end{tabular}

As depicted in Table 2, all experts give high scores with entirely very valid categories with an average of 4.74. Based on this, the media developed seemed to satisfy the experts who gave the assessment but still provided some suggestions for improvement. Some suggestions are given by the two related media experts: less structured installation, usage and troubleshooting instructions; program design that is still less effective; the unity aspect which consists of the use of visual and audio languages still seems less harmonious and comprehensive; and in the aspect of navigation, some symbols used must be replaced by familiar symbols to be easily recognized and effective in their use. Meanwhile, some suggestions were given by the two related material experts: the addition of images, diagrams and illustrations contained in daily life; and on the aspects of material presentation, additional material must be interactive and participatory to maximize student involvement in the learning process. Based on these suggestions, we revised the multimedia.

After repairs to the media based on advice from experts, the media is then tested on students in one to one try out evaluation, small group evaluation, and field evaluation. Of the three trials, students highlighted the readability of material content so that most students suggested that the letters and alloys of the background color be adjusted to make it easy to read. Students provide some very good responses to the display of videos and animations that are very interesting to make students more enthusiastic in learning mathematics and delivering material that I easily understand to encourage students to learn independently. The multimedia display of the development results in this study is shown in Figure 2.
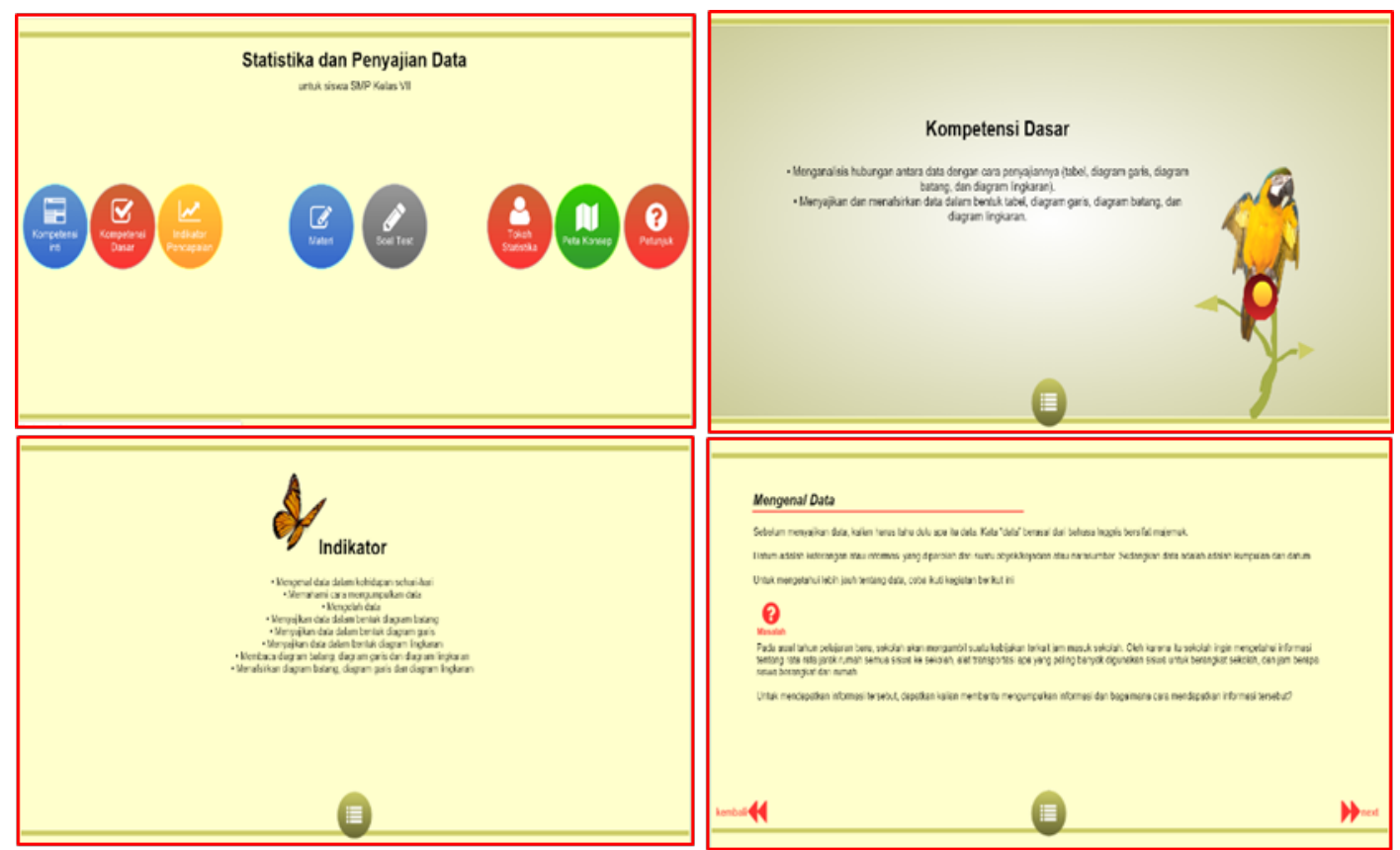

Figure 2. Display of developed multimedia 
As explained in Figure 2, is an example of the final product of the multimedia display developed. The image consists of the initial appearance of the media, basic competencies, indicators, and data presentation methods.

\section{Summative Evaluation}

Summative evaluation is done to test the effectiveness of the use of CAI on mathematical representation capabilities. Data analysis was performed to test the comparison of the increase in mathematical representation ability between the experimental group and the control group and the difference in the increase in the ability of mathematical representation based on the students' initial ability level. To see the increase in mathematical representation capabilities achieved by students and their qualifications used normalized ngain data. The normalized n-gain value average is an illustration of the increase in mathematical representation ability between the two research groups. The difference in increasing the ability of mathematical representation can be seen in Table 3 .

Table 3. The Mean of N-gain Mathematical Representation Mean

\begin{tabular}{|c|c|c|c|c|}
\hline $\begin{array}{c}\text { Category of Students' basic } \\
\text { ability (SBA) }\end{array}$ & Learning model & Mean & Std. Deviation & $\mathbf{N}$ \\
\hline \multirow{3}{*}{$x^{2}$} & CAI & .6100 & .11460 & 4 \\
\hline & Non CAI & .2257 & .10814 & 7 \\
\hline & Total & .3655 & .22033 & 11 \\
\hline \multirow{3}{*}{ Middle } & CAI & .6130 & .20598 & 27 \\
\hline & Non CAI & .2765 & .13264 & 20 \\
\hline & Total & .4698 & .24398 & 47 \\
\hline \multirow{3}{*}{ High } & CAI & .6383 & .21377 & 6 \\
\hline & Non CAI & .3050 & .15901 & 8 \\
\hline & Total & .4479 & .24596 & 14 \\
\hline \multirow{3}{*}{ Total } & CAI & .6168 & .19539 & 37 \\
\hline & Non CAI & .2729 & .13345 & 35 \\
\hline & Total & .4496 & .24051 & 72 \\
\hline
\end{tabular}

As can be seen in Table 3, the mathematical representation ability of the experimental group students had a greater average gain than the control group students $(0.6168>0.2729)$. This shows that the increase in mathematical representation ability of the experimental group students is higher and more diffuse than the mathematical representation ability of the control group students. To test the hypothesis above, a two-way analysis of variance (ANOVA) was conducted with the General Linear Model (GLM) - Univariate conducted at a significance level of $5 \%(\alpha=0.05)$. The results of the analysis are shown in Table 4.

Table 4. The Analysis of Mathematical Representation Ability Gain Variance Based on Learning Model and Students' basic ability (SBA)

\begin{tabular}{lccccc}
\hline \multicolumn{5}{c}{ Dependent Variable: N-gain Kemampuan Representasi } & F \\
\hline Source & Type III Sum of Squares & Df & Mean Square & Sig. \\
\hline Corrected Model & $2.155^{\mathrm{a}}$ & 5 & .431 & 14.567 & .000 \\
\hline Intercept & 9.229 & 1 & 9.229 & 311.980 & .000 \\
\hline KAM & .017 & 2 & .009 & .290 & .749 \\
\hline Model & 1.440 & 1 & 1.440 & 48.679 & .000 \\
\hline SBA * Model & .005 & 2 & .003 & .087 & .917 \\
\hline Error & 1.952 & 66 & .030 & & \\
\hline Total & 18.660 & 72 & & & \\
\hline Corrected Total & 4.107 & 71 & & & \\
\hline
\end{tabular}

a. $\mathrm{R}$ Squared $=.525$ (Adjusted R Squared $=.489$ )

As depicted in Table 4, to test the first hypothesis about the comparison of the increase in mathematical representation ability, the significance value (Sig.) of $0,000<\alpha=0.05$ and Fcount $=48,679>$ F0.05 $(2 / 72)=$ 3.12. So it can be concluded that the increase in the ability of mathematical representation of students studying with ICT-based mathematics learning CAI models with multimedia is better than students who obtain learning with non-ICT-based mathematics learning CAI models with multimedia. Furthermore, to test the second hypothesis about the differences in the increase in mathematical representation ability based on 
the level of students' initial abilities obtained a significance value (Sig.) of $0.749>\alpha=0.05$ and Fcount $=2.90$ $<$ F0.05 $(2 / 72)=3,12$. So it can be concluded that there is no difference in the increase in the ability of significant mathematical representation between students with high, medium and low ability levels.

\section{DISCUSSION}

Based on the analysis carried out by the stages of research, CAI learning developed through multimedia has met very good standards by expert assessment and trials conducted before media products are declared final. At the summative evaluation stage, overall students give a good response to the multimedia display developed. Multimedia content is recognized by experts and pilot students to be able to illustrate various mathematical concepts. Based on the results of the effectiveness test, the use of CAI in learning is effective in improving students' mathematical representation skills. The effectiveness of CAI used in learning is inseparable from the use of multimedia which was developed based on systematic stages through the stage of needs analysis, development of learning design, expert validation and rigorous trials. The stages that go through produce multimedia that is suitable in CAI learning. Students are allowed to represent various forms of mathematical concepts that are presented into different representations. The system developed was able to construct a learning model with self-regulated learning and establish complete learning habits based on a tutorial model that requires students to complete the mathematical concepts learned before continuing learning on more difficult concepts. Learning that is designed systematically and structured can facilitate students in learning mathematical concepts as a whole and comprehensively.

The significant increase in the ability of mathematical representation of experimental class students was also followed by positive attitudes of students in learning. This is under the results of previous studies which stated that the use of digital-based learning materials can improve attitudes towards mathematics learning (Chen et al., 2015). The effectiveness of CAI is influenced by students' interest in multimedia that is developed with content consisting of notes, graphics, images, audio, video, and animation. Description of mathematical concepts conveyed with clear and integrated narratives with graphic, image and audio displays can increase the concentration of students learning the concepts presented. CAI programs generally tend to be effective in initiating reading instructions (Blok, Oostdam, Otter, \& Overmaat, 2002). Other studies that focus on the use of pictorial representations find that their use is effective in providing stimuli for solving everyday problems (Willis \& Fuson, 1988). ICT development provides convenience in multimedia development, including alternatives in developing animation.

Animation developed provides convenience for students in seeing problems with interesting visualizations that resemble the original form. The display of interactive animation allows students to quickly find effective ways of solving problems in mathematics learning (Mišútová \& Mišút, 2012). Representations that involve observing an object are known as visual representations. This visual representation in CAI learning is a bridge for students in translating and transforming representations into different forms. Creating a visual representation in maximizing thinking skills in mathematics learning is important as an effort to develop students' mathematical concepts (Schoenfeld, 2013). This finding is in line with the findings of previous studies stating that describing problems visually can increase students 'conceptual and procedural knowledge (RittleJohnson \& Star, 2007), expressing students' thinking (Carreira, 2015), able to facilitate students to recall previous mathematical knowledge (Pape, 2004), and assist students in integrating various new information presented (Abdullah et al., 2012).

The research findings show that CAI can be used to visualize abstract mathematical concepts, but must be supported through the concept of multimedia development with communicative, interactive, comprehensive, integrated, coherent, and providing feedback to students. Digital media can refine mathematical objects more than just expressions, algorithms, or mathematical symbols by conceptualizing and developing situations based on images, schematic representations, languages, letters, and available iconic elements (Carreira, 2015). In the perspective of ICT-based learning, other researchers conclude that ICT can involve the active role of students in learning (Oktavianingtyas, Salama, Fatahillah, Monalisa, \& Setiawan, 2018). The appearance of attractive media for students is also able to motivate and erode students' saturation in mathematics learning.

It cannot be denied that student enthusiasm in learning can be one of the factors that influence learning effectiveness. The CAI model proved to be able to stimulate students' enthusiasm in learning mainly because the media developed was interactive. These results are relevant to other studies which show that interactive learning media have a good effect on self-efficacy (Psycharis \& Kallia, 2017), and are feasible to use because they can help students learn as a subject of direct and inverse proportions and see student value preferences 
(Oktavianingtyas et al., 2018). Based on the perspective of ICT learning, other researchers mention that multimedia content has an effect on students' interest in learning and focusing their attention because the concepts of the material being studied are supported interactively in learning (Munir, 2012), able to facilitate communication so as to maximize the effectiveness and achievement of learning objectives to the full maximum (Newby, Stepich, Russell, \& Lehman, 2006).

This potential is by the standards of mathematical processes which are an integral part of the components of mathematical representation capabilities. Representation is an important process in learning that functions in developing and optimizing students' thinking skills, the construction process and the abstraction of mathematical knowledge (Rahmawati et al., 2017). The CAI model which is designed by maximizing the translation and transformation process of various forms of representation becomes a bridge for students to interpret the various mathematical ideas they have. Various forms of representation that are visually observed by students provide unlimited access to students to explore various forms of representation that are used as a process of solving real problems. The use of representation can support students' understanding, especially in solving mathematical problems or learning new mathematical concepts (Salkind \& Hjalmarson, 2007). So that it cannot be denied that mathematics requires representation, conversely representation requires visualization to facilitate the translation and transformation process itself.

However, we need to be aware of the difficulties of students in the process of mathematical representation which is usually didactic because of learning barriers. In this regard, we can understand mathematical representation as an ability that does not stand alone in the cognitive structure of students. Mathematical representation is a conceptual composite (consisting of configuration ideas) that is not easily understood by students so it is recommended that class discussions help students understand ideas embedded in mathematical representations to avoid students using procedurally representation without intact understanding (Abrahamson, 2006). The emphasis on the importance of class discussion is the embodiment of the process of socialization in learning which is nothing but referred to as socio-mathematics. This conception is in line with the effectiveness of ICT learning also stated by other researchers, who stated that ICT has great potential in expanding and increasing the availability of learning aids for students because it can provide opportunities for students to be creative, have skills, sharpen talents, and to practice social skills in the learning process (O’Hara, 2008).

The role of the teacher as a facilitator in CAI is especially important in helping students find mathematical ideas through a two-way communication process. ICT learning has the potential to make learning less developed if conceptualized by reactive supervision by overriding interactions that are guided directly by the teacher in a pedagogic manner (Plowman \& Stephen, 2003) so that the use of ICT in learning should be carried out with teacher supervision and guidance. Adult guidance is needed to support children in getting and investigating ideas about mathematical concepts (Björklund, 2010). Thus, the development of CAI should not only focus on the appearance and content that is interesting because it can potentially eliminate the process of communication between teachers and students. Paying attention to the appropriateness of the content, material substance, the feasibility of material presentation, and contextual assessment must be the focus of substance in CAI learning, especially those carried out through multimedia development. Substantive material should be shown coherently to make multimedia more effective and efficient (Munir, Kusnendar, \& Rahmadhani, 2016).

The research findings are relevant to similar studies that show CAI contributes to facilitating better social competence and communication in young children with autism (Bernard-Opitz, Sriram, \& Nakhoda-Sapuan, 2001), computer-based interventions can produce changes in skills broader cognitive and social aspects in a cost-effective manner and time Skills in Students with ASD (Rice, Wall, Fogel, \& Shic, 2015), to supplement a phonics-based reading curriculum that is able to improve phonological awareness in early literacy skills for kindergartners (Macaruso \& Rodman, 2011), potentially effective for improving students' mathematical performance with LD (Seo \& Woo, 2010), able to improve verbal skills and language, but not mathematical skills but function as a substantial scaffold (Shute \& Miksad, 1997), capable addressing problems related to improving student achievement and mathematical performance (Tienken \& Wilson, 2007), and produce superior academic achievements in mathematics from basic concepts to algebra and geometry (Brown, 2000).

In closing the discussion in this study, we want to emphasize the importance of mathematical representation as a distinctive ability in mathematics. Educators must maximize the potential of students' mathematical representation through integration between mathematical knowledge possessed by the selection of models, strategies, and media used in learning. If this is done, it is not impossible that learning can be a conductor for developing mathematical representation capabilities. This, in line with other 
researchers who say that the knowledge of mathematics becomes an important part of teaching is the ability to produce and use representations (Salkind \& Hjalmarson, 2007). Knowledge of mathematics, pedagogical knowledge, the ability to select learning models and the selection of instructional media by teachers comprehensively have strong potential in developing students' mathematical representations.

\section{CONCLUSION}

CAI conducted through the development of interactive multimedia using hippo animator software has met the standards in the process of research and development carried out through the stages of needs analysis, learning design, media production, formative evaluation, and summative evaluation. Based on the CAI perspective we conclude that CAI intervention through multimedia development has a very strong influence on learning so that it can be used as the main alternative in learning. In this study, we developed multimedia with a tutorial model. So, we suggest the selection of new strategies both related to programming and the CAI model developed in subsequent research to increase more varied support.

\section{ACKNOWLEDGEMENT}

On this occasion the author would like to express his appreciation and gratitude to the Directorate of Research and Community Service (DRPM) as a sponsor of the collaborative university research grant scheme, teachers and students of Public Islamic Junior High School called State of Madrasah Tsanawiyah (MTsN) 3 Kuningan, and all those who had a major impact on success and completion of this study. The author realizes that this article is far from perfect, therefore constructive criticism and suggestions are needed for the perfection of this article. Hopefully, this research is useful for readers.

\section{Disclosure statement}

No potential conflict of interest was reported by the authors.

\section{Notes on contributors}

Uba Umbara - STKIP Muhammadiyah Kuningan, Kuningan, Indonesia \& School of Postgraduate Studies, Universitas Pendidikan Indonesia, Bandung, Indonesia.

Evan Farhan Wahyu Puadi - STKIP Muhammadiyah Kuningan, Kuningan, Indonesia.

Munir - Universitas Pendidikan Indonesia, Bandung, Indonesia.

Rudi Susilana - Universitas Pendidikan Indonesia, Bandung, Bandung, Indonesia.

\section{REFERENCES}

Abdullah, N., Zakaria, E., \& Halim, L. (2012). The effect of a thinking strategy approach through visual representation on achievement and conceptual understanding in solving mathematical word problems. Asian Social Science, 8(16), 30. https://doi.org/10.5539/ass.v8n16p30

Abrahamson, D. (2006). Mathematical representations as conceptual composites: Implications for design. In Proceedings of the Twenty Eighth Annual Meeting of the North American Chapter of the International Group for the Psychology of Mathematics Education (Vol. 2, pp. 464-466).

Adu-Gyamfi, K., Stiff, L. V, \& Bossé, M. J. (2012). Lost in translation: Examining translation errors associated with mathematical representations. School Science and Mathematics, 112(3), 159-170. https://doi.org/10.1111/j.1949-8594.2011.00129.x

Afriyani, D., Sa'dijah, C., Subanji, S., \& Muksar, M. (2018). Characteristics of Students' Mathematical Understanding in Solving Multiple Representation Task based on Solo Taxonomy. International Electronic Journal of Mathematics Education, 13(3), 281-287. https://oi.org/10.12973/iejme/3920

Ainsworth, S. (2006). DeFT: A conceptual framework for considering learning with multiple representations. Learning and Instruction, 16(3), 183-198. https://doi.org/10.1016/j.learninstruc.2006.03.001

Andrà, C., Arzarello, F., Ferrara, F., Holmqvist, K., Lindström, P., Robutti, O., \& Sabena, C. (2009). How students read mathematical representations: An eye tracking study. In Proceedings of the 33rd Conference of the International Group for the Psychology of Mathematics Education (Vol. 2, pp. 49-56). 
Anohina, A. (2005). Analysis of the terminology used in the field of virtual learning. Journal of Educational Technology \& Society, 8(3), 91-102.

Bal, A. P. (2015). Skills of using and transform multiple representations of the prospective teachers. ProcediaSocial and Behavioral Sciences, 197, 582-588. https://doi.org/10.1016/j.sbspro.2015.07.197

Bernard-Opitz, V., Sriram, N., \& Nakhoda-Sapuan, S. (2001). Enhancing social problem solving in children with autism and normal children through computer-assisted instruction. Journal of Autism and Developmental Disorders, 31(4), 377-384. https://doi.org/10.1023/A:1010660502130

Björklund, C. (2010). Broadening the horizon: Toddlers' strategies for learning mathematics. International Journal of Early Years Education, 18(1), 71-84. https://doi.org/10.1080/09669761003661246

Blok, H., Oostdam, R., Otter, M. E., \& Overmaat, M. (2002). Computer-assisted instruction in support of beginning reading instruction: A review. Review of Educational Research, 72(1), 101-130. https://doi.org/10.3102/00346543072001101

Brown, F. (2000). Computer Assisted Instruction in Mathematics Can Improve Students' Test Scores: A Study. Bruner, J. S. (1966). Toward a theory of instruction (Vol. 59). Harvard University Press.

Cai, J., \& Lester Jr, F. K. (2005). Solution representations and pedagogical representations in Chinese and US classrooms. The Journal of Mathematical Behavior, 24(3-4), 221-237. https://doi.org/10.1016/j.jmathb.2005.09.003

Carbonell, J. R. (1970). AI in CAI: An artificial-intelligence approach to computer-assisted instruction. IEEE Transactions on Man-Machine Systems, 11(4), 190-202. https://doi.org/10.1109/TMMS.1970.299942

Carreira, S. (2015). Mathematical problem solving beyond school: Digital tools and students' mathematical representations. In Selected regular lectures from the 12th international congress on mathematical education (pp. 93-113). https://doi.org/10.1007/978-3-319-17187-6_6

Cathcart, W. G., Pothier, Y. M., Vance, J. H., \& Bezuk, N. S. (2000). Learning mathematics in elementary and middle schools. Prentice Hall Allyn and Bacon.

Chang, K.-E., Chen, Y.-L., Lin, H.-Y., \& Sung, Y.-T. (2008). Effects of learning support in simulation-based physics learning. Computers \& Education, https://doi.org/10.1016/j.compedu.2008.01.007

Chen, M.-J., Lee, C.-Y., \& Hsu, W.-C. (2015). Influence of mathematical representation and mathematics selfefficacy on the learning effectiveness of fifth graders in pattern reasoning. International Journal of Learning, Teaching and Educational Research, 13(1).

Cuban, L. (2009). Oversold and underused. Harvard university press. https://doi.org/10.2307/j.ctvk12qnw

De Witte, K., Haelermans, C., \& Rogge, N. (2015). The effectiveness of a computer-assisted math learning program. Journal of Computer Assisted Learning, 31(4), 314-329. https://doi.org/10.1111/jcal.12090

Dick, W., Carey, L., \& Carey, J. O. (2015). The systematic design of instruction. 8th. United States Of.

Gagatsis, A., \& Elia, I. (2004). The Effects of Different Modes of Representation on Mathematical Problem Solving. International Group for the Psychology of Mathematics Education.

Gagatsis, A., \& Shiakalli, M. (2004). Ability to translate from one representation of the concept of function to another and mathematical problem solving. Educational Psychology, 24(5), 645-657. https://doi.org/10.1080/0144341042000262953

Gall, M. D., Gall, J. P., \& Borg, W. R. (2007). Educational research: an introduction (8. utg.). Boston: Pearson/Allyn and Bacon.

Goldin, G. A. (1998). Representational systems, learning, and problem solving in mathematics. The Journal of Mathematical Behavior, 17(2), 137-165. https://oi.org/10.1016/S0364-0213(99)80056-1

Goldin, G. A., \& Kaput, J. J. (1996). A joint perspective on the idea of representation in learning and doing mathematics. Theories of Mathematical Learning, 397.

Haidar, N., Obeed, S., \& Jawad, M. (2011). Mathematical representation of bolted-joint stiffness: A new suggested model. Journal of Mechanical Science and Technology, 25(11), 2827-2834. https://doi.org/10.1007/s12206-011-0725-0

Hake, R. R., \& others. (1999). Analyzing change/gain scores (Unpublished) [Online] Retrieved from http://www.Physics.Indiana.Edu/ Sdi/AnalyzingChange-Gain.Pdf 
Janvier, C. E. (1987). Problems of representation in the teaching and learning of mathematics. In This book stems from a symposium organized by CIRADE (Centre Interdisciplinaire de Recherche sur l" Apprentissage et le Développement en Education) of Université du Que1bec abec abec abec abec abec abec abec abec abec abec abec abec abec abec abec à Montr.

Kaput, J. J. (1987). Representation systems and mathematics. Problems of Representation in the Teaching and Learning of Mathematics, 19, 26.

Killpatrick, J., Swafford, J., \& Findell, B. (2001). Adding it up: Helping children learn mathematics. Washington, DC: National Academy Press.

Lesh, R., Landau, M., \& Hamilton, E. (1983). Conceptual models and applied mathematical problem-solving research. Acquisition of Mathematics Concepts and Processes, 263-343.

Lesh, R., Post, T. R., \& Behr, M. (1987). Representations and translations among representations in mathematics learning and problem solving. In Problems of representations in the teaching and learning of mathematics. Lawrence Erlbaum.

Macaruso, P., \& Rodman, A. (2011). Efficacy of computer-assisted instruction for the development of early literacy skills in young children. Reading Psychology, 32(2), 172-196. https://doi.org/10.1080/02702711003608071

Macaruso, P., \& Walker, A. (2008). The efficacy of computer-assisted instruction for advancing literacy skills in kindergarten children. Reading Psychology, 269-287. https://doi.org/10.1080/02702710801982019

McCoy, L. P., Baker, T. H., \& Little, L. S. (1996). Using multiple representations to communicate: An algebra challenge. Communication in Mathematics, K-12 and beyond (1996 Yearbook) Reston, Va: NCTM.

Minarni, A., \& Napitupulu, E. E. (2017). Developing Instruction Materials Based on Joyful PBL to Improve Students Mathematical Representation Ability. International Education Studies, 10(09), 23-38. https://doi.org/10.5539/ies.v10n9p23

Minarni, A., Napitupulu, E., \& Husein, R. (2016). Mathematical understanding and representation ability of public junior high school in north sumatra. Journal on Mathematics Education, 7(1), 43-56. https://doi.org/10.22342/jme.7.1.2816.43-56

Mišútová, M., \& Mišút, M. (2012). Impact of ICT on the Quality of Mathematical Education. In Proceedings of the 6th International Multi-Conference on Society, Cybernetics and Informatics (pp. 76-80).

Munir, Kusnendar, J., \& Rahmadhani. (2016). Developing an effective multimedia in education for special education (MESE): An introduction to arithmetic. In AIP Conference Proceedings (Vol. 1708, p. 50001). https://doi.org/10.1063/1.4941159

Munir, M. (2012). Multimedia konsep \& aplikasi dalam pendidikan. Bandung: Alfabeta.

NCTM. (2000). Principles and standards for school mathematics (Vol. 1). National Council of Teachers of.

Newby, T. J., Stepich, D. A., Russell, J. D., \& Lehman, J. D. (2006). Educational technology for teaching and learning. Prentice Hall.

Nguyen, T. T., Hui, S. C., \& Chang, K. (2012). A lattice-based approach for mathematical search using formal concept analysis. Expert Systems with Applications, 39(5), 5820-5828. https://doi.org/10.1016/j.eswa.2011.11.085

Noblesse, F., Delhommeau, G., Huang, F., \& Yang, C. (2011). Practical mathematical representation of the flow due to a distribution of sources on a steadily advancing ship hull. Journal of Engineering Mathematics, 71(4), 367-392. https://doi.org/10.1007/s10665-011-9453-9

O'Hara, M. (2008). Young children, learning and ICT: A case study in the UK maintained sector. Technology, Pedagogy and Education, 17(1), 29-40. https://doi.org/10.1080/14759390701847443

Oktavianingtyas, E., Salama, F. S., Fatahillah, A., Monalisa, L. A., \& Setiawan, T. B. (2018). Development 3D Animated Story as Interactive Learning Media with Lectora Inspire and Plotagon on Direct and Inverse Proportion Subject. In Journal of Physics: Conference Series (Vol. 1108, p. 12111). https://doi.org/10.1088/1742-6596/1108/1/012111

Pape, S. J. (2004). Middle school children's problem-solving behavior: A cognitive analysis from a reading comprehension perspective. Journal for Research in Mathematics Education, 187-219. https://doi.org/10.2307/30034912

Pape, S. J., \& Tchoshanov, M. A. (2001). The role of representation (s) in developing mathematical understanding. Theory into Practice, 40(2), 118-127. https://doi.org/10.1207/s15430421tip4002_6 
Pennington, R. C. (2010). Computer-assisted instruction for teaching academic skills to students with autism spectrum disorders: A review of literature. Focus on Autism and Other Developmental Disabilities, 25(4), 239-248. https://doi.org/10.1177/1088357610378291

Plowman, L., \& Stephen, C. (2003). A 'benign addition'? Research on ICT and pre-school children. Journal of Computer Assisted Learning, 19(2), 149-164. https://doi.org/10.1046/j.0266-4909.2003.00016.x

Psycharis, S., \& Kallia, M. (2017). The effects of computer programming on high school students' reasoning skills and mathematical self-efficacy and problem solving. Instructional Science, 45(5), 583-602. https://doi.org/10.1007/s11251-017-9421-5

Rahmawati, D., Hidayanto, E., Anwar, R. B., \& others. (2017). Process of Mathematical Representation Translation from Verbal into Graphic. International Electronic Journal of Mathematics Education, 12(3), 367-381.

Renshaw, C. E., Taylor, H. A., \& Reynolds, C. H. (1998). Impact of computer-assisted instruction in hydrogeology on critical-thinking skills. Journal of Geoscience Education, 46(3), 274-279. https://doi.org/10.5408/1089-9995-46.3.274

Rice, L. M., Wall, C. A., Fogel, A., \& Shic, F. (2015). Computer-assisted face processing instruction improves emotion recognition, mentalizing, and social skills in students with ASD. Journal of Autism and Developmental Disorders, 45(7), 2176-2186. https://oi.org/10.1007/s10803-015-2380-2

Richards, C. (2005). The design of effective ICT-supported learning activities: Exemplary models, changing requirements, and new possibilities. Language Learning \& Technology, 9(1), 60-79.

Rittle-Johnson, B., \& Star, J. R. (2007). Does comparing solution methods facilitate conceptual and procedural knowledge? An experimental study on learning to solve equations. Journal of Educational Psychology, 99(3), 561. https://doi.org/10.1037/0022-0663.99.3.561

Salkind, G. M., \& Hjalmarson, M. (2007). Mathematical representations. George Mason University.

Schoenfeld, A. H. (2013). Cognitive science and mathematics education. Routledge.

Seo, Y.-J., \& Woo, H. (2010). The identification, implementation, and evaluation of critical user interface design features of computer-assisted instruction programs in mathematics for students with learning disabilities. Computers \& Education, 55(1), 363-377. https://doi.org/10.1016/j.compedu.2010.02.002

Shute, R., \& Miksad, J. (1997). Computer assisted instruction and cognitive development in preschoolers. Child Study Journal, 27(3), 237-253.

Supandi, S., Waluya, S. B., Rochmad, R., Suyitno, H., \& Dewi, K. (2018). Think-Talk-Write Model for Improving Students' Abilities in Mathematical Representation. International Journal of Instruction, 11(3), 77-90. https://doi.org/10.12973/iji.2018.1136a

Surya, E., Sabandar, J., Kusumah, Y. S., \& Darhim, D. (2013). Improving of junior high school visual thinking representation ability in mathematical problem solving by CTL. Journal on Mathematics Education, 4(1), 113-126. https://doi.org/10.22342/jme.4.1.568.113-126

Tandiling, E. (2015). Effectivity of Problem Based Learning (PBL) in improving students' mathematical representation. In Proceeding of International Conference on Research, Implementation, and Education of Mathematics and Sciences (p. 151).

Thomas, L., \& Knezek, D. (2002). Standards for technology-supported learning environments. The State Education Standard, 3(3), 14-20.

Tienken, C. H., \& Wilson, M. J. (2007). The Impact of Computer Assisted Instruction on Seventh-Grade Students' Mathematics Achievement. Planning and Changing, 38, 181-190.

Van Scoyoc, A. M. (2003). Reducing library anxiety in first-year students: The impact of computer-assisted instruction and bibliographic instruction. Reference \& User Services Quarterly, 329-341.

Warsito, Darhim, \& Herman, T. (2018). Improving students' mathematical representational ability through RME-based progressive mathematization. In Journal of Physics: Conference Series (Vol. 948, p. 12038). https://doi.org/10.1088/1742-6596/948/1/012038

Widakdo, W. A. (2017). Mathematical Representation Ability by Using Project Based Learning on the Topic of Statistics. In Journal of Physics: Conference Series (Vol. 895, p. 12055). https://doi.org/10.1088/17426596/895/1/012055

Wieczorek, M., \& Lewandowski, M. (2017). A mathematical representation of an energy management strategy for hybrid energy storage system in electric vehicle and real time optimization using a genetic algorithm. Applied Energy, 192, 222-233. https://doi.org/10.1016/j.apenergy.2017.02.022 
Willis, G. B., \& Fuson, K. C. (1988). Teaching children to use schematic drawings to solve addition and subtraction word problems. Journal of Educational Psychology, 80(2), 192. https://doi.org/10.1037/00220663.80.2.192

Yerushalmy, M. (1997). Designing representations: Reasoning about functions of two variables. Journal for Research in Mathematics Education, 28(4), 431. https://doi.org/10.2307/749682

Zaitseva, E., \& Levashenko, V. (2013). Multiple-valued logic mathematical approaches for multi-state system reliability analysis. Journal of Applied Logic, 11(3), 350-362. https://doi.org/10.1016/j.jal.2013.05.005

Zhang, L., Watson, E. M., \& Banfield, L. (2007). The efficacy of computer-assisted instruction versus face-toface instruction in academic libraries: a systematic review. The Journal of Academic Librarianship, 33(4), 478-484. https://doi.org/10.1016/j.acalib.2007.03.006 